\title{
Autobiographies: a tool to depict English language learning experiences'
}

\section{Autobiografías: una herramienta para representar experiencias de aprendizaje del idioma inglés}

\author{
Julia Posada-Ortíz and Eliana Garzón-Duarte ${ }^{2 *}$ \\ Universidad Distrital Francisco José de Caldas, Colombia
}

\begin{abstract}
This article contains a description of a research project carried out with a group of English Language Pre-service Teachers (ELPTs) of a state University in Bogotá, Colombia. The purpose of the study was to portray the experiences, feelings and insights the ELPTs went through as English language learners. Autobiographies was the instrument to collect data. The results show that the English language learners' process of learning has a strong influence of the language policies connected to the National Program of Bilingualism. They also show that it is necessary to create a cumulative program of English for each phase of schooling in order to avoid overlapping and to provide a more motivating learning process. The conclusions confirm that through the implementation of autobiographies in the EFL classroom, teachers can feel connected to their students and understand their learning needs and interests from a more personal perspective.
\end{abstract}

Key words: Autobiography; Autobiographical research; English Language Learning; Motivation in Language Learning; National Program of Bilingualism.

\section{Resumen}

Este artículo contiene la descripción de un proyecto de investigación que se llevó a cabo con 26 estudiantes de un programa de licenciatura en inglés de una universidad pública en Bogotá, Colombia. El propósito del estudio fue retratar las experiencias de los estudiantes como aprendices de lengua, sus sentimientos y puntos de vista al respecto. La autobiografía fue el instrumento que se utilizó para recoger datos. Los

1 Received: September 8th 2018/ May 15th 2019

2 jzposadao@gmail.com; eliaga@yahoo.com 
resultados muestran que el proceso de aprendizaje de lengua tiene una fuerte influencia del Programa Nacional de Bilingüismo. También evidencian la necesidad de crear un currículo de inglés más amplio e incluyente, que tenga en cuenta lo aprendido en las diferentes etapas de la escuela para evitar la repetición de contenidos y propiciar un aprendizaje más motivador. En las conclusiones se confirma que la implementación de autobiografías en el aula de inglés como lengua extranjera permite a los profesores entender las necesidades e intereses de sus estudiantes desde una perspectiva más personal.

Palabras clave: Autobiografía; Investigación autobiográfica; Aprendizaje del inglés; Motivación en el Aprendizaje de Lenguas; Programa Nacional de Bilingüismo.

\section{Resumo}

Este artigo contém a descrição de um projeto de pesquisa que se realizou com 26 estudantes de um programa de licenciatura em inglês de uma universidade pública em Bogotá, Colômbia. O propósito do estudo foi retratar as experiências dos estudantes como aprendizes de língua, seus sentimentos e pontos de vista ao respeito. A autobiografia foi o instrumento que se utilizou para coletar dados. Os resultados mostram que o processo de aprendizagem de língua tem uma forte influência do Programa Nacional de Bilinguismo. Também evidenciam a necessidade de criar um currículo de inglês mais amplo e incorporador, que leve em consideração o aprendido nas diferentes etapas da escola para evitar a repetição de conteúdos e propiciar uma aprendizagem mais motivadora.

Palavras chave: Autobiografia; Pesquisa autobiográfica; Aprendizagem do inglês; Motivação na Aprendizagem de Línguas; Programa Nacional de Bilinguismo 


\section{Introduction}

$\mathrm{A}$ s one of the requirements for the subject Language, Society and Culture in one B.Ed. program of English Teaching in a public university in Bogotá, the teacher-researcher asked her students to write autobiographies, as a reflective methodology to know the connections student-teachers made with the process of learning and teaching English as a Foreign Language in the Colombian context. By reading these autobiographies, she observed that the student-teachers struggled to be able to understand the classes they receive mainly in English during the first semesters of the program. She also realized they made use of some specific strategies in order to overcome their difficulties. Therefore, she started to do research with the 26 students who were taking this subject during the first semester of 2015 to delve into their experiences as English learners and future teachers of English.

This article presents the purposes, method, theoretical framework and results of this research. The insights derived from this work might help teacher educators to understand how the students make sense of their experience as language learners and what needs to be done in order to be more effective English teachers not only at the university, but also in basic levels, namely primary and secondary education. Nevertheless, we would like to clarify that this article does not have a prescriptive intention whatsoever.

\section{Theoretical Framework}

In this section, we will define autobiography and autobiographical research in education. We will also illustrate how learning a language is influenced by socio-cultural factors and different forms of orientation in motivation. Finally, we will provide a brief description of the National Program of Bilingualism in Colombia.

\section{Autobiography}

Autobiography is one form of narrative among blogs, stories, journals, interviews essays and others. A narrative is a "recounting of things spatiotemporarilly distant" (Toolan, 2001, p.1). Distant refers to the tale and its topic, and also to the reader and teller. Narratives always include stories about people, their memories and reflections, the connections they make between their past and present and the sense they make out of their lived experiences. Autobiographies provide us with a great opportunity to see our actions and our journey through life under certain circumstances. In this particular case, the students had the chance to reflect on their experience as language learners in their Basic Education and at the Bachelor program. They enjoyed the writing 
of this experience as it will be shown in the data analysis and the researcher was delighted to learn from their experiences.

An autobiography is "the story of the memory of oneself, one's history and its critical moments" (Hernández et al., 2011, p. 29). Gusdorff (1991) highlights the etymological components of the word autobiography which make it a complex concept. Autos refers to the identity, the consciousness of oneself and the principle of an autonomous existence, Bios affirms the vital continuity of that entity and its historical development; finally, Graphe introduces the technical means used to describe the development of that self. In the case of autobiography, the means is the written word.

Autobiography is one of the objects of study of autobiographical research. Being autobiography one of the objects of study of autobiographical research, we can define this type of research as the one that "explores the interweaving between language, thought and social practice. It examines how individuals integrate, structure, interpret spaces and temporalities of their historical and cultural contexts to examine, in that way, the process of construction of the subject (or group) in the dialectical interaction between social space and personal space through (the) language(s)" (Passeggi, 2011, p. 29).

\section{Autobiographical research in education}

Autobiographical research in education has been done through four waves. The first wave began in the early $70 \mathrm{~s}$ in the USA and it was designated as autobiography and curriculum. This type of research focused on the analysis of the understandings and meanings of students in initial training. It included the reconstruction of autobiographical stories from the perspective of the curriculum as text and gender identity. The second wave embraced stories of experience and narrative (Grummet, 1988, 1991; Pagano, 1990). In this type of research, the researchers collected observations, diaries, conversations and documents that constitute narratives in order to reconstruct the experience that produces personal knowledge. In this wave there was an intense study of feminism. The third wave was related to collaborative autobiographies in which the researcher and the participants classified the autobiographies according to themes and patterns and made a report of their perspectives (Butt \& Raymond, 1988) (Schubert \& Ayers, 1992) (Goodson, 1998; Goodson \& Cole, 1993). This process allowed the creation of a shared professional culture and identity.

Finally, we have the recent tendency to use narratives and stories in order to comprehend the history of education. This way has two trends. The first one includes personal stories examined only by the researcher and the second one 
is focused on the life of the teachers that are examined by the teachers and the researcher. The research described in this article can be framed in the one that includes personal stories (the ones written by the students) and examined by the teacher researcher.

In Colombia some scholars such as Durán, Lastra \& Morales (2013); and Villarreal, Muñoz \& Perdomo (2016) have used autobiographies and narratives as a means to understand how people see life and construct meaning out of their experiences. In the first case, with college students and, in the second one, with students from 6th and 11th grades and their beliefs about the English classes. Other studies include the life stories of Colombian teachers, as it is the case of Clavijo's (2000) research.

The writing of an autobiography fosters a process of reflection that accounts for a better comprehension of the contexts and views of the world of the person who writes, which in turns reverts in a possible benefit as it gives voice to the voiceless and allows the implementation of changes and reforms based on the knowledge of the conditions narrated by the person who experiments the tensions and conflicts involved in living under certain circumstances.

The particular autobiographies analyzed in this project shed light on the needs of the students in their language learning process as well of the learning strategies they use in order to improve their language skills. The autobiographies also showed the tensions the future teachers go through and the different representations of the academic life. In this sense, this project might contribute to introduce some innovations in the English program of the major in which this study took place.

\section{Motivation in language learning}

According to Williams and Burden (1997), learning another language is different from learning any other subject. The learning of a foreign language implies more than just developing a set of skills, vocabulary and grammar; it entails "an alteration in self-image, the adoption of new social and cultural behaviors and ways of being, and therefore has a significant impact on the social nature of the learner" (p. 115).

Crookall and Oxford (1988) state that learning another language is "ultimately learning to be another social person" (p. 136). Gardner (1985) adds that "Languages are unlike any other subjects in that they involve the acquisition of skills and behavior patterns which are characteristic of another community" (p. 146). Consequently, learning a foreign language will be influenced by the attitudes towards the particular community of speakers of that language. 
Language learning is also affected by the context and the culture in which learning takes place. In Colombia "speaking English has been deified as an asset in the sense that it only brings benefits to those who learn it, mainly as the access to a modern world characterized by technology, wider communication, economic power, scientific knowledge, and the like" (Maurais, 2003 as cited in Guerrero, 2010.). Thus, a concern that emerges in the Colombian context is to know what makes someone interested in learning English. So here, it is important to explain the difference between integrative and instrumental orientation in motivation (Gardner, 1985). An integrative orientation "occurs when the learner is studying a language because of a wish to identify with the culture of speakers of that language" (Williams \& Burden, 1997, p. 116). An instrumental orientation describes a "group of factors concerned with motivation arising from external goals such as passing exams, financial rewards, furthering a career and gaining promotion" (Williams \& Burden, 1997, p. 116). According to the results of this study, it could be interpreted that the students' orientation in their motivations seems to be instrumental as most of them reported to be interested in the English language as the means to obtain better job positions and be able to travel and achieve their goals.

The instrumentalization and usefulness orientation in motivation to learn English in the imagining of the students and their relatives might evidence the strong influence of the national policies "in times in which languages are stratified according to their instrumental value in the job market, and languages such as English gain a higher status based on the assumption that they provide better possibilities for employment and traveling" (Usma, 2009, p.132). Therefore, this study is focused on a cognitive approach to motivation which "is concerned with such issues as why people decide to act in certain ways and what factors influence the choices they make" (Williams \& Burden, 1997, p. 119).

\section{The National Program of Bilingualism}

In 2005, the Ministry of Education released The National Program of Bilingualism in Colombia, a long-term policy that aimed "to make Colombian citizens bilingual in Spanish and English by 2019” (Usma, 2009, p. 128). This program was implemented focusing on five main areas, (1) developing standards for English teaching and learning; (2) evaluating communicative

166 competence in students as well as in-service and pre-service teachers within and outside the formal school system; (3) providing professional development programs for teachers in order to develop their pedagogical knowledge as well as communicative competence in English; (4) supporting the use of new information and communication technologies for the teaching of English; and (5) consolidating bilingual and trilingual models in the different ethnic communities around the country (Cely, 2007). 
The program designated the British Council as the leading implementation agency around the country, and Cambridge University Press would be in charge of testing teachers and students, as well as publishing the materials that would serve as a reference for the plan. This program was criticized by scholars in Colombia, who identified some flaws in its implementation such as the reduction of the term bilingualism to speaking English and Spanish, the processes of inclusion of the British Council and other international companies to support the program, and the exclusion of national universities and the instrumentalization of language learning among others.

As a way to mediate in the academic discussion, the Government changed the name of the National Program of Bilingualism into National English Program 2015-2025. The program "seeks students to use English as a tool to communicate with the world and improve their career opportunities strategy" (Presidencia de la República, 2014). This program is focused on three main areas: 1) Strategies for teacher training and teaching materials for primary and secondary education; 2) Quality, support and funding for higher education; and, 3) Coordination with the productive sector. Once again, the new program relies on the British Council and Cambridge as leading agencies to accompany the process.

The implementation of the National Program of Bilingualism brought the implementation of testing the English level of students and teachers and rose the demand for English teachers especially in Primary education where the teaching of this language should start. It also gave great relevance to the use of ICTs in education. The implementation of the Program did not take into account neither local needs nor the differences between rural and urban areas and private and state schools.

Although there is a good intention from the part of the government to make people able to speak another language, they did not consider other language possibilities and they adopted English as the only language worth learning. The government, as stated previously, did not take into account local needs and contexts and, in this way, "the uncritical adoption of bilingual models brings to light, as a consequence, that the good intention of giving everybody access to a language of power ends in an even more unequal distribution of material and symbolic resources" (Guerrero, 2010, p. 168). The students' autobiographies evidenced some of the flaws in the implementation of this program, being the most remarkable ones the unequal distribution of resources and the shortage of English teachers in primary schools. They also declared the big social difference between the English teaching in private institutions and the one offered by state schools, where the conditions are not the same, even when the National English Program has common objectives for all the levels of the educational system in Colombia. 


\section{Research Design}

In this section, the context, participants, methodology, and data analysis of the research will be presented. The four categories derived from the data analysis are explained. These categories are entitled as (1) My experience as a young learner of English, (2) Reasons for learning another language, (3) Making sense of my academic life, and (4) Visions of teaching.

\section{Context and participants}

This study took place at a state university in Bogotá, Colombia. It was carried out with 26 sixth-semester students from a language teacher education program. The students took the subject called Language, Society and Culture. This subject was taught in a four-hour period a week, during 16 weeks in the first semester 2015. The students' age ranked between 20 and 25 years old. The participants volunteered to take part of the project and the type of work was piloted with a similar population in the two previous semesters. Language, Society and Culture belongs to the Disciplinary field of this Bachelor's Program and it is oriented to raise student teachers' awareness of the elements involved in language and their connections with society development and cultural views. Reflection is a key factor in this subject.

\section{Aims, methodology and data collection instruments}

The first aim of inquiry was to describe the language learning experiences of the student teachers and to characterize the main and most significant experiences they went through. In order to achieve these objectives, the narrative inquiry that entails "learning about the content of the experiences of the participants and their reflections" (Barkhuizen, 2013, p. 8) was used.

Narrative inquiry is also defined by Connelly and Clandinin as "the study of experience as story" (2006, p. 477). According to Barkhuizen (2013), these authors incite the researcher to go deeper in the context and the content of these stories in terms of temporality (the times in which experiences unfold), place (the places where the experiences are lived), and sociality (personal emotions, desires and interactions between people).

Incited by Connelly \& Clandinin (2006), the content and the form of the students' autobiographies were analyzed and this analysis led to identify that their temporality was framed within the times of the implementation of the National Program of Bilingualism with all its vices. It was also noticeable in the autobiographies that the student teachers went through experiences in state and private institutions and that the latter offer them better opportunities 
to learn the foreign language. Finally, it was read about their feelings when learning English, their dreams, and relationships between their classmates and language teachers, not only in their basic education, but also at the university.

In order to analyze the autobiographies, the theoretical framework and ideas of Riessman (2000), Hernández \& Rifà (2011), and Barkhuizen (2013) were used. The main source of data was the autobiographies written by the students following some items based on questions about their English learning experience. An analysis of the structure and content of the autobiographies was carried out, but the emphasis was done on the latter.

Regarding the structure, it was found that most of the narratives started with an introductory paragraph, they continued describing the experiences with the English Language at school, family and college. Most of them finished with a description of future plans and some of the narratives had an abrupt end. The following section will describe the four categories of analysis.

\section{Category 1: My experience as a young learner of English}

As the student-teachers included their experience in Primary and Secondary School, this part of the narrative structure was called My experience as a young learner of English.

"In Primary school I had one teacher who was in charge of all of the subjects. That teacher had little knowledge about English...when I was in secondary school, I had a good teacher in my English class" (C.G. 2015:1).

The experiences depicted by the students had in common that most of the times they had only one teacher in Primary school and that teacher was in charge of teaching all the subjects including English. Therefore, their experience in Primary was reduced to learning lists of vocabulary and one or two songs. Some of the students had a better experience in their secondary school and a few of them decided to study in a language institute in order to improve their language skills or to prepare themselves to be admitted in the university. Being private schools and institutes the places where students found better opportunities to improve their English might evidence that the conditions in which English is being taught and used in Colombia "puts the population which does not have the material, economic, or human resources to access the L2 at a disadvantage" (Guerrero, 2010, p. 176).

The fact that most of the students were taught English in Primary school by the homeroom teacher who was the teacher in charge of all of the subjects brings about the problem the national policies related to learning English has in common with other countries. In 1994, the Ministry of Education, in 
its General Law of Education, introduced in Colombia "the need to learn at least one foreign language starting in elementary school" (Usma, 2009, p. 127). Nevertheless, this policy as it happened all around the world had some effects on the teaching and learning practices being the most remarkable "the shortage of primary school teachers with an English specialism. As a result, homeroom teachers, who may only speak limited English, are often required to take English lessons" (Copland \& Garton, 2014, p. 225). This fact supports Quintero and Guerrero's (2013) claim that educational policies ignore, silence, and make teachers in general invisible as their opinions are not taken into account and they have to "find ways to make them (the policies) meaningful for their students in their particular context. This implies that sometimes they (the teachers) have to skip some of them (the policies) and adapt others; all this in order to, as they say, do the best for our students" (p. 202).

\section{Category 2: Reasons for learning another language}

When reading the narratives, one of the most interesting things was to discover the students' reasons for learning English. It could be noticed that their motivation was high and that it came from different sources, having some of them an instrumental orientation and external influences such as key people and events.

The cognitive concept of motivation, construed as "a state of cognitive and emotional arousal, which leads to a conscious decision to act, and which gives rise to a period of sustained intellectual and/or physical effort in order to attain a previously set goal (or goals)" (William \& Burden, 1997, p. 120), is the concept that frames this research. There was an emotional arousal in all the autobiographies derived from an instrumental orientation and external influences. This emotional arousal made the students invest not only money, but also intellectual and physical effort to learn the language. The following lines explain the external influences that boosted students' interest in English.

\section{a. Perceived value of learning English}

As stated in the theoretical framework, from a cognitive perspective "motivation is concerned with such issues as why people decide to act in certain ways and what factors influence the choices they make" (William \& $170 \quad$ Burden, 1997, p. 119).

When the reason for performing an activity lies within the activity itself, we are talking about intrinsic motivation: "When the only reason for performing and activity is to gain something outside the activity itself, such as passing an exam, or obtaining financial rewards, the motivation is likely to be extrinsic" (William \& Burden, 1997, p. 123). 
The students involved in the project were sometimes intrinsically motivated and sometimes extrinsically. For instance, most of them showed preference for English and they invested time and effort. However, they were also interested because learning English represents social status and gain (better job opportunities, travelling and interacting with people from other cultures).

The sustained effort students made in learning English came from the fact that they gave a great value to the language in terms of what it represented in their long-term goals and life projects:

"I have always liked traveling (sic), learning new things, new cultures and learn from the world above (sic). English is considered as the universal language, for that reason, I thought that learning languages could be necessary to accomplish my expectations" (A.C. 2015:1).

"One day I was talking with my father and he told me that I had to study something that opens doors everywhere..." (M.G. 2015:1).

b. Curiosity

One of the major components of motivation is curiosity. Curiosity is inherent to human beings. The student teachers' curiosity started when they heard new songs, came across books written in English and learned about new cultures:

"I found some books of Meyer's Institute and looked at the images of London and some comics and I was interested because I did not understand anything so, I took a dictionary, some cassettes and tried to understand what those books were saying" (F.B. 2015:1).

\section{c. Key people}

The interest in the English language was also created by the influence of some relatives and teachers who not only made the students like the language, but also made them think about becoming an English teacher.

"My sister in law was the person who influenced me in become a teacher (sic)" (p.3).

"Teachers like him are persons who leave a mark in you and make you want to follow their lives and examples (sic)" (J.P.R. 2015:1).

d. Key events

There were also key events such as school performances and going to the movies that engaged students in the liking of English:

"An important tradition at school was to prepare a big role play to present at Santo Tomas University and only the best students could participate 
in it. So, I think that I did my best to belong to that "privileged group" (E.S. 2015:1).

"The only reason I had to learn English when I was a child was the fact that I wanted to understand movies language..." (F.R. 2015:1).

\section{Category 3: Making sense of my academic life}

According to Passegi (2011), one of the three principles that guide research on autobiographies is the construction of reality. This is the moment in which the writer links past and present and how this link has made him or her what he or she is now. The autobiographies showed positive and negative experiences that influence the students' decisions to continue improving their language learning. In the process of overcoming the difficulties when learning English, students become agents of their own language learning process.

"I think that the best experience I have ever had in (the B.Ed. program), was in first semester, the English teacher I had at that stage was simply amazing, and I learnt a lot from him. He made me feel sure about this career, and about being an English teacher. Clearly, that experience, made me continue in the program" (S.B. 2015:1).

Students' academic life was permeated by some tensions that had mainly to do with abrupt changes from one teaching style to another. Some students were highly motivated by the English teachers they had in primary and then they found that their secondary English teachers were absolutely different. The same was true for the university experience. Some of the students stated that the teachers at the university do not take into account students' needs:

"This experience has been very different at the university because... (teachers do not) do activities according to our needs" (L.R. 2015:1).

There is a mismatch between what their teachers at the university preach and what they do in class:

"Talking about my experiences at the University on the [...] program I have to say that most of the English teachers are focused on theories and sometimes they do not encourage students to learn English as a whole" (F.B. 2015:1).

"Sometimes teachers do not help enough..." (A.C. 2015:1).

Besides the aspects mentioned above, students see the university as a world of dichotomies; some classmates are selfish, some others cooperate:

"When I started my degree, I was so confused because I really loved English...but the subjects (sic) did not make me feel good, the people 
were arrogant and I never received help from anyone so I started failing and delayed (sic) one semester" (D.H. 2015:1).

Academic life is full of challenges. Students have to perform some activities in English even at early stages of the B.Ed. program, when they do not feel confident enough to do so, and sometimes they feel at a disadvantage towards their peers. These situations create tensions and force the students to search a way through to overcome limitations:

"My English classes were awful, and sad sometimes, because I could not understand a lot of things..." (E.A. 2015:2).

"Many of my classmates had a good level ...so I felt very shy and ashamed to speak" (J.R. 2015:1).

Students become agents of the B.Ed. program as they undergo some aspects of the university within certain dichotomies such as good and bad teachers, good and bad experiences. However, they are also agents as they find ways to overcome the problems.

"I had a terrible teacher, so I realized that it is too important the autonomous work. That's why I started to improve by myself, watching movies, reading books, looking for free English courses online, talking to native English speakers in chat rooms, and so on" (C.S. 2015:2).

They also read or look for alternative ways to practice English, such as English Clubs or groups of people who join foreigners in places for this purpose. The interest of some students is also focused on culture:

"I like to read newspaper articles [...] There are also some places in Bogotá where you have the opportunity to speak with native speakers, depending of your level (sic) and that's a good tool because is the closest chance that you have to know about English people and their culture" (D.N. 2015:2).

To sum up, students look for different ways to face all the challenges of their academic life and succeed. We could say that they do a lot with English outside the classroom and they are autonomous, definitely agents of their own learning process.

\section{Category 4: Visions of teaching}

As the participants are student-teachers of English, it was important to analyze their visions as future teachers. They still have a romantic view of teaching and they foresee themselves as humanistic teachers that will improve education and change the world. For them, it is paramount to teach another 
language as a way to help people. One of the most important points to highlight is that they want to continue their preparation with further studies:

"A teacher is someone who helps people, who teaches, who listens, who understands, and who loves the profession and obviously is a person who changes the world" (J.A. 2015:2).

"I would like to discover all the stories behind every student and use that in a future to analyze the best way to teach them" (S.H. 2015:2).

"In the future I see myself as teacher researcher" (F.B. 2015:2).

It is important to highlight that students' visions of the teacher have a lot to do with the pedagogical and humanistic aspects. Students recognize teaching as a profession and some of them are clear about having a role as teacher researchers as well. Teacher development is an ongoing process that makes part of their life project.

\section{Conclusions and implications}

The main purposes that guided this project were to describe the language learning experiences of the student-teachers and to characterize the main and most significant experiences they went through. We described the English language learners' experiences in terms of four categories entitled as follows: My experience as a young learner of English, Reasons for learning another language, Making sense of my academic life, and Visions of teaching.

The experiences depicted by the future teachers showed a strong influence of the National Program of Bilingualism with all its flaws, especially the fact that English was adopted as the main foreign language to be taught and learnt giving this language a status "even higher than the mother tongue in Colombia" (Guerrero, 2010). Thus, the participants' narratives portrayed interesting insights about the way global and local factors are affecting English learning and teaching in Colombia.

The global policies about learning English from an early stage derived from the market have reached our country and have had an impact on our Primary and Preschool programs. We could see from the autobiographies that they depict "A widely reported problem...the gap between the supply of qualified TEYL (Teaching English to Young Learners) teachers and the demand for them as programs expand..." (Enever \& Moon, 2009, p. 10). The lack of qualified teachers means that countries frequently have to rely on teachers "who are not trained to teach TEYL, including Primary class teachers and others who might not have qualifications appropriate for teaching younger children" (Enever \& Moon, 2009, p. 10). 
Most of the students claimed to have been taught English in Primary school by teachers who were not prepared to do so, and therefore they were requested to learn long lists of vocabulary or do translations. They also stated that these classes were mainly taught by their homeroom teacher who was in charge of all of the subjects. This might show how the policies on learning English whose implementation started in our country in 2005 with the National Program of Bilingualism did not supply sufficient qualified language teachers in Primary schools and how the teachers faced this problem trying to do what was best for their students. It also shows that these policies were top-down and did not take into account local needs and contexts.

In the second category, namely reasons for learning another language, we can see the instrumentalization of language learning (Usma, 2009) as the main reason to learn English. The students perceived the value of this language as the means to travel and get better job opportunities which turns English into "an instrumental tool to be "competitive" in the job market and the "knowledge based economy" (Usma, 2009, p. 133). According to Usma, the instrumentalization of language learning is one of the effects of the international policies adopted by Colombia in the National Program of Bilingualism.

At the university, the students found that they were not progressing in their learning of the English as a foreign language, as the information they receive does not seem to have continuity. This might evidence the need to establish "a cohesive curriculum outline in foreign languages, ensuring a cumulative program of provision for each phase of schooling" (Enever \& Moon, 2009, p. 12).

The student teachers feel their English teachers' discourse is not coherent to what they do in class and that they should make their classes more interesting and focused on students' interests. Although students reported to do a lot of autonomous work mainly by using the ICTs (chats, television, network), they still acknowledge the need for a teacher who accompanies their process and helps them with some tutoring more than one who makes a lot of use of ICTs in class. Teacher who helps, understands them and foremost loves his or her profession.

The previous paragraphs probably describe the most interesting finding which has to do with what the student teachers expect from their language teachers. Student teachers did not claim for a teacher using new technologies in class. They look for a teacher who is aware of what they already know, their needs and interests and someone who is a more like a councilor to their difficulties.

We wanted to highlight the use of the ICTs and the students' image of a good teacher because ICTs are also part of the global policies in education and the nowadays called Plan Nacional de Inglés (National English Plan). The 
use of ICTs is mandatory as one of the resources that should be implemented in class. This aspect needs revision as focusing too much in the ICTs as the only means to engage students in tasks related to learning languages, so this might lead to a distorted view of teaching and learning. Looking for fun activities and getting to know our students better can lead them to progress as well. By stating this, we do not mean we should exclude ICTs as part of our practice as language teachers, what we would like to emphasize is that there are other alternatives being the most important carrying out needs analysis in order to know what our students already bring, need to learn and how they learn. Therefore, the use of the ICTs and the new environments for learning should be evaluated in terms of "an understanding of the extent to which they enhance the learning experience" (Enever \& Moon, 2009, p. 11.)

It was interesting to note that the visions of teaching pre-service teachers have, has to do with providing useful learning experiences and be able to match their students' needs. Only two students out of the 26 envision themselves as a teacher researcher and all of them established being a teacher as part of their life project. On a more personal note, we would like to add that by reading these narratives we got to know our students better. It was easier to understand the way they behave in the classroom and, of course, it made us feel more connected with them.

Finally, it is important to state that the findings of this project might shed a light on some of the effects of the National Program of Bilingualism. As for the B.Ed. program, where this study took place, it would be interesting to consider an evaluation of the English syllabus offered, in terms of the continuity suggested by the results. This evaluation could be extended to primary and secondary levels of education, where the students also mentioned have been exposed to overlapping of topics that led to a loss of interest in the English classes. 


\section{References}

Barkhuizen, G. (2013). Narrative research in Applied Linguistics. Cambridge: CUP.

Butt, R. \& Raymond, D. (1988). Biographical and contextual influences on an "ordinary" teacher's thoughts and actions. In J. Lowyck, C. Clarke, \& R. Halkes (Eds.), Teacher thinking and professional action. Lisse, Holland: Swets \& Zeitlinger.

Cely, R. M. (2007). Una Colombia bilingüe. Entrevista con Rosa María Cely. Eleducador.com, November 12, 2007. Retrieved from: https://es.scribd. com/document/35373482/Entrevista-Rosa-M-Cely

Clavijo, A. (2000). Formación de maestros, Historia y Vida: reflexión y praxis del maestro colombiano acerca de la lectura y la escritura. Bogotá: Plaza y Janés.

Connelly, F. M. \& Clandinin, D. J. (2006). Narrative Inquiry. In J. L. Green, G. Camilli, \& P. B. Elmore (Eds.), Complementary methods for research in education (pp. 477-487). Mahwah, NJ: Lawrence Erlbaum.

Copland, F. \& Garton, S. (2014). Key themes and future directions in teaching English to young learners: Introduction to the Special Issue. ELT Journal, 68(3), 223-230.

Durán, N., Lastra, S., \& Morales, A. (2013). Autobiographies: A way to explore student- Teachers' beliefs in a teacher education program. Profile Issues in Teachers' Professional Development, 15 (2), 35-47.

Enever, J. \& Moon, J. (2009). New global contexts for teaching primary ELT: Change and Challenge . In J. Enever, J. Moon, \& U. Raman (Eds.), Young Learners English Language Policy and Implementation: International Perspectives (pp. 5-22). Reading, UK: Garnet Education.

Gardner, R. C. (1985). Social Psychology and Language Learning: the role of attitudes and motivation. London: Edward Arnold.

Goodson, I. (1998). Storing the self: Life politics and the study of teachers' life and work. In W. F Pinar (Ed.), Curriculum toward new identities (pp. 3-20). New York/London: Garland Publishing.

Goodson, I. \& Cole, A. (1993). Exploring the teachers' professional knowledge.

In D. McLauglhin \& W. Tierney (Eds.), Naming silenced lives: Personal narratives and the process of educational change (pp. 71-94). New York: Routledge.

Grummet, M. (1988). Bitter milk: Women and teaching. Amherst, MA: University of Massachussets Press. 
Guerrero, C. H. (2010). Elite vs. Folk Bilingualism: The mismatch between theories and educational and social conditions. How, 17(1), 165-179.

Gusdorff, G. (1991). Lignes de vie 2. Auto-biographie. Paris: Odile Jacob.

Hernández, F. \& Rifà, M. (2011). Investigación autobiográfica y cambio social. Barcelona: Octaedro.

Pagano, J. (1990). Exiles and Communities: Teaching in the Patriarchal Wilderness. Albany, NY: State University of New York Press.

Passegi, M. (2011). Aproximaciones teóricas a las perspectivas de la investigación autobiográfica en educación. Revista Educación y Pegagogía, 23(61), 25-40.

Presidencia de la República (2014). Programa Nacional de Inglés 20152025 'Colombia, very well', pondrá a hablar inglés a los colombianos. Retrieved from: http://wsp.presidencia.gov.co/Prensa/2014/Julio/ Paginas/20140710 05-Programa-Nacional-de-Ingles-2015-2025Colombia-very-well-pondra-a-hablar-ingles-a-los-colombianos.aspx

Quintero, A. \& Guerrero, C. H. (2013). “Of Being and not Being:” Colombian Public Elementary School Teachers' Oscillating Identities. How, 20(1), 190-205.

Riessman, C. (2012). Analysis of personal narratives. In J. F. Gubrium, J. A. Holstein, A. B. Marvasti, \& K. D. McKinney (Eds.), The SAGE Handbook of interview research: The complexity of the craft (Ch. 25). London, UK: SAGE Publications.

Schubert, W. \& Ayers, W. (1992). Teacher Lore: Learning from our own experience. New York: Longman.

Toolan, M. (2001). Small stories, positioning analysis, and the doing of professional identities in learning to teach. Narrative Inquiry, 17, 371-89.

Usma, J. (2009). Education and language policy in Colombia: Exploring processes of inclusion, exclusion, and stratification in times of global reform. Profile Issues in Teachers' Professional Development, 11(2), 123141.

Villarreal, J., Muñoz, J. V., \& Perdomo, J. M. (2016). Students' Beliefs about Their English Class: Exploring New voices in a National Discussion. Profile Issues in Teachers' Professional Development, 18(2), 139-150.

Williams, M. \& Burdens, R. L. (1997). Psychology for language teachers. A social constructivist approach. Cambridge: CUP. 


\section{Authors}

*Julia Posada-Ortiz is a doctoral candidate in Education with an emphasis in ELT at Universidad Distrital Francisco José de Caldas. She holds an M.A in Applied Linguistics to TEFL from Universidad Distrital Francisco José de Caldas, a Specialization in Literature Teaching from Universidad del Quindío-Coruniversitaria and a B.Ed. in English and Spanish Teaching from Universidad del Tolima. She is an Associate Professor in the Faculty of Sciences and Education at Universidad Distrital Francisco José de Caldas and a member of the research group Aprendizaje y Sociedad de la Información.

ORCID: https://orcid.org/0000-0001-8919-5286

Eliana Garzón-Duarte is a doctoral candidate of English Applied Linguistics at the University of Szeged, in Hungary, as a scholarship holder from the Stipendium Hungaricum Program. She holds an M.A. in Language Teaching from Universidad Pedagógica y Tecnológica de Colombia. She is a full-time teacher of the Faculty of Education at Universidad Distrital Francisco José de Caldas. Her research interests are identity construction, language education, language rights, linguistic diversity and social justice.

ORCID: https://orcid.org/0000-0001-5920-1550

How to reference this article: Posada-Ortiz, J., \& Garzón-Duarte, E. (2019). Autobiographies: a tool to depict English language learning experiences. GiST Education and Learning Research Journal, 18, 161-179. https://doi.org/10.26817/16925777.447 